\title{
Onuncu Yılında Suriyeli Sığınmacıların Kente Entegrasyonu ve Gelecek Beklentileri: Batman Örneği
}

\section{Muzaffer BiMAY'}

\section{Öz}

Bu çalışma, 2010 yılının son ayında birçok Arap ülkesinde başlayan ve 2011 yılının Nisan ayında Suriye'de devam eden iç çatışmalar nedeniyle kaçan sığınmacıların entegrasyon sürecini ve geleceğe ilișkin beklentilerini Batman kenti örneğinde ele almayı amaçlamıştır. Buradan hareketle, sığınmacıların bulundukları kent ortamındaki sosyal ve kamusal çevreyle olan ilişkilerinin son on yılda geldiği aşama ve sığınmacılar için oluşturulan geçici koruma mevzuatı kapsamında entegrasyonun önemli göstergelerinden barınma, dil, eğitim, istihdam ve vatandaşlık süreçlerinin gerçekleşme düzeyleri elde edilen bulguların analiziyle ortaya çıkarılmıştır. Ayrıca bu çalışma ile sığınmacıların, Suriye Savaşına ve dolayısıyla kendi geleceklerine ilişkin nasıl bir tutum içinde olacakları ile ilgili beklentileri de ele alınmıştır. Bu bağlamda yapılan saha araştırmasında nicel araştırma yöntemi benimsenmiş, göç ve göçe ilişkin kavramsal çerçeveyi içine alan teorik arka plandan sonra araştırmanın hedef evrenini oluşturan Batman kentinde yaşayan Suriyeli sığınmacılara yönelik yapılan saha araştırmasının bulguları analiz edilmiştir. Bu çerçevede sığınmacıların içinden 18 yaşından büyük 134 katılımcı ile yüz yüze anketler yapılmıştır. Anketler 2020 yılının Mayıs ve Haziran aylarında uygulamalı bir alan araştırması şeklinde gerçekleştirilmiştir. Araştırmaya katılan Suriyeli sığınmacıların kente entegrasyonu sanılanın aksine beklentileri karşılamadığı, savaşın uzaması ve ekonomik sıkıntıların artması nedeniyle gelecek ile ilgili kaygılarının arttığı ortaya çıkmıştır. Buna rağmen sığınmacıların umutlarını kaybetmedikleri elde edilen bulgulardan anlaşılmıştır. Dolayısıyla sığınmacılara yönelik sosyo-ekonomik ve kültürel etkileşimi içeren çok kapsamlı yeni bir entegrasyon politikasına ve düzenlemelere ihtiyaç olduğu söylenebilir. Sığınmacı ve mülteci konusunun artan göçlerle gündemi meşgul etmesi beklenirken bu ve benzeri çalışmaların araştırmacılar ve yöneticiler için kılavuz niteliği taşıması hedeflenmektedir.

Anahtar Kelimeler: Göç, Kent, Entegrasyon, Sığınmacı, Mülteci, Batman

1 Öğr. Gör. Dr., Batman Üniversitesi Sosyal Bilimler Meslek Yüksek Okulu, Mülkiyet Koruma ve Güvenlik Bölümü, muzafferbimay@gmail.com, ORCID ID: 0000-0002-6742-2852. 


\title{
Integration of Syrian Asylum Seekers in the Urban and Future Expectations in Its Tenth Year: The Case of Batman
}

\begin{abstract}
This study aims to discusses the integration process of the Syrian asylum seekers in Batman city in Turkey and their expectations from the future as asylum seekers, who left their homeland and moved to many Arab countries due to the internal conflict in Syria in 2010. From this point of view, the stage of the relations of asylum seekers with the social and public environment in the urban environment in which they live and the level of realization of accommodation, language, education, employment and citizenship processes, which are among the important indicators of integration within the scope of the temporary protection legislation created for the refugees, have been revealed by the analysis of the findings. In addition, with this study, the expectations of the asylum seekers regarding the Syrian War and their attitude towards their own future were taken into consideration. In this context, the mixed research method based on qualitative and quantitative data was adopted in the paper. After the theoretical background has been given, the paper includes the conceptual framework of migration and migration, the findings of the field study conducted on Syrian asylum seekers living in Batman, which constitutes the target universe of the research, were analyzed. In this framework, face-to-face surveys were conducted with 134 participants over 18 years old among the asylum seekers. The surveys were conducted in May and June 2020 as an applied field study. It was revealed that the Syrian asylum seekers participating in the research did not meet the expectations contrary to what is believed, and their concerns about the future increased due to the prolongation of the war and the increase in economic problems. Despite the fact that these problems, it was understood from the findings that the asylum seekers did not lose their hope. Therefore, it can be said that there is a need for a very comprehensive new integration policy and regulations that include socio-economic and cultural interaction for asylum seekers. While the issue of asylum seekers and refugees is expected to occupy the agenda with increasing migration, it is aimed that these and similar studies will serve as a guide for researchers and administrators.
\end{abstract}

Keywords: Migration, Urban, Integration, Asylum Seekers, Refugee, Batman

\section{Extended Abstract}

Migrations have an important effect on shaping the urban life. As a result of forced migration, especially resulted by war, conflict etc., not only physical displacement but also different social interactions and cultural differences take place. As a result of the interactions of different social groups living in the urban with migration, social, economic and cultural integration problems arise in terms of asylum. As the duration of stay of immigrants is extended, sometimes comprehensive integration including citizenship, socio-economic and cultural interaction can be achieved, but sometimes 
separation and conflict may arise between asylum seekers and local people living in the urban, which may also lead up to psychological and sociological disruptions. Similarly, evaluating asylum seekers in a different refugee status defined in international law can also be effective in conducting the problematic transition of the integration process. The aim of this study is to discuss the integration process and prospective expectations of the Syrian asylum seekers in urban space of Batman who fled the internal conflicts that had started in many Arab countries in the last month of 2010 and continued in Syria in April 2011. The number of the asylum seekers is around 4 million today and the social importance of the asylum seekers in Turkey within the context of upcoming integration process is increasing day by day. The long lasting process of the integration of asylum seekers, the continuation of the migration process, their temporary status in the different cities of Turkey demonstrate that this process needed to be studied in more detail. Therefore, it is important to deal with the social and spatial problems of the asylum seekers residing in Batman, which have experienced rapid urbanization processes with internal and external migration since the $1940 \mathrm{~s}$ with the discovery of oil reserves around the city. From this point of view, at the end of the ten-year period that has passed since the first day of the migration flows from the 2010 onwards, the relationships of the asylum seekers with the social and public space, their social, economic, cultural and environmental problems in the urban places and their attitudes and expectations regarding the future have been tried to be explained by the analysis of the findings. The mixed research method based on qualitative and quantitative data was adopted, and after the theoretical background that included the conceptual framework on migration, the findings obtained from the field research were interpreted by making descriptive analysis. Among the Syrian asylum seekers living in Batman, which constitutes the target population of the study, 134 sample groups over the age of 18 were selected and face-to-face surveys were conducted with them. The surveys were conducted in May and June 2020 as an applied field study. Based on the results obtained due to the venue's proximity and safety of participants, their choosing Turkey as a country of immigration, expensiveness of rents for the immigrants, the language problem were considered to cause significant economic problems such as inability to find work outside of unskilled jobs. Therefore, it was understood that the integration processes of the participants were very painful, Syrian asylum seekers were generally pessimistic about their prospective expectations, socio-economic and cultural integration failed, and therefore they were willing and expectant to return to Syria. Although the intensity of the civil war in Syria has been decreased, the low density of asylum seekers and refugees issues on the agenda of Turkey will continue and the engagement with the ongoing migration and integration is expected to be even more troubled now. For this reason, it is necessary for asylum seekers to benefit from public and urban services unconditionally, to realize all necessary arrangements, including granting refugee status, as soon as possible, and to implement a comprehensive new integration policy that includes socioeconomic and cultural interaction. Thus, it is thought that psychological and sociological disintegration such as alienation and exclusion caused by 
Onuncu Yılında Suriyeli Sığınmacıların Kente Entegrasyonu ve Gelecek Beklentileri: Batman

Örneği

integration can be prevented. Syrian asylum seekers in Turkey and issues of the world will emerge when the topic from the agenda blurs, and in particular will increase the need for similar studies, from which researchers and managers will benefit. 


\section{Giriş}

Göç, toplumların sosyo-ekonomik ve kültürel yapılarını oluşturan, etkileyen, değiştiren en önemli sosyal olaylardan birisidir (Akkayan, 1979). Söz konusu sosyal olay, mekân ve zaman boyutunu da içeren uzun soluklu bir süreci kapsamaktadır. Bu süreç başta barınma, dil sorunu, sağlık, eğitim, iş ve vatandaşlık olmak üzere toplumsal etkileşimi içeren çok kapsamlı bir entegrasyon içermektedir (Penninx ve Spencer, 2008; Fielden, 2008; Ager ve Strang, 2004). Ancak özellikle uluslararası zorunlu kitlesel göçlerle büyüyen kentlerde entegrasyon zorlu ve sancılı geçmekte ve bu süreç zamanla toplumsal bir soruna dönüşmektedir (Chambers, 1986; Jacobsen, 2006). Bu nedenle entegrasyon süreçlerinin daha uygun bir ortamda gerçekleşebilmesi için yeni tip göç politikalarına ve yerel, ulusal ve uluslararası iş birliğine ihtiyaç duyulmaktadır (Joppke, 2012).

Dünyada uluslararası zorunlu göçe dayalı olarak yerinden olanların sayısı, 2016 yılı sonu itibarıyla 65,6 milyon, 2017 yılında 68,5 milyon dolayında olduğu ve bu sayının bugün itibarıyla 70.8 milyon kişiye ulaştığı belirtilmektedir. 2050 yılına gelindiğinde ise bu sayının 230 milyon olacağı tahmin edilmektedir (The UN Refugee Agency [UNHCR], 2020; International Organization for Migration [IOM], 2020). Günümüzde yaşanan zorunlu göçlerin önemli oranı ise 2011 yılında Kuzey Afrika'da ortaya çıkan ve daha sonra Orta Doğu'da yayılan halk kalkışmalarının Suriye'ye sıçramasıyla yaşanan iç savaşla ortaya çıkmıştır (Philips, 2012). 2012 yılının ilk ayında dünyadaki Suriyeli mülteci sayısı 9,500 iken 2015'te 4,088,078'e, 2016'da 4,718,230'a ve 2020 yılında yaklaşık 5.6 milyona yükselmiştir. Bu sayının, ülke içinde yerinden edilenlerle birlikte 6.6 milyonun üzerinde olduğu tahmin edilmektedir (UNHCR, 2020). Günümüzde halen devam eden Suriyeli sığınmacı göçüne en çok maruz kalan ülke ise 3.626,734 (14 Ekim 2020) kişi ile Türkiye'dir (Göç İdaresi Genel Müdürlüğü [GiGM], 2020). Bu sebeple, başlangıçta geçici olarak görülen, ancak savaşın uzamasıyla birlikte kalıcı hale gelen bu büyüklükteki sığınmacı göçü (Yıldırımalp, İslamoğlu ve İyem, 2017: 107) ile ilgili kente entegrasyonun hangi düzeyde olduğu, kalıcı olmaları beklenilen sığınmacıların gelecekten beklentilerinin neler olduğu, entegrasyonun sağlanması ve geleceğe umutla bakılması için hangi yol ve yöntemlerin izlenmesi gerektiği ile ilgili yanıtlanması gereken birçok soru karşımıza çıkmaktadır.

Bu çalışmanın amacı, son on yılda Batman kentine göç eden Suriyeli sığınmacıların kente entegrasyon süreci ve bu sürece bağlı olarak gelecekten nasıl bir beklenti içinde olduklarını ortaya koyabilmektir. Türkiye, son zamanlarda yoğun bir göçe maruz kalmış ve bu göçlerle ilgili ülke içinde birçok saha araştırması yapılmıştır. Ancak Batman özelinde, Türk'ün (2020b) Suriyelilerin vatandaşlığa geçme konusundaki tutumlarına ilişkin çalışması dışında kayda değer herhangi bir çalışmanın olmadığı söylenebilir. Dolayısıyla Batman kenti özelinde yapılan bu çalışma ile yapılacak saptamalar ve elde edilecek bulguların gelecekte göç ve kent literatürüne önemli katkılar sunması hedeflenmektedir. 


\section{Göç ve Kent ile ilgili Temel Kavramlar}

İnsanlık tarihiyle var olan ve her dönemde güncelliğini koruyan göç olgusu, sosyal, ekonomik, siyasal ve kültürel sebeplere dayalı olarak farklı mekânlarda, farklı şekil ve yöntemlerle gerçekleşmekte ve etkileri de bunlara bağlı olarak değişebilmektedir. Bu mekânsal hareketlilikler neticesinde göç edenler, fiziksel bir yer değiştirme olayının yanında maddi ve manevi tüm değerlerini de göç ettikleri mekânlara taşıdıklarından dolayı ciddi anlamda toplumsal değişimin ana unsuru haline gelmektedirler (Bulut ve Eraldemir, 2015: 16). Bu sebeple göç literatüründe birçok farklı kavramla karşılaşma durumu ortaya çıkmaktadır.

Literatürde birbirleriyle ilintili olarak kullanılan göç, kent, entegrasyon kavramlarına ilişkin birçok tanımlama yapılmıştır. Genel olarak göç, "belirlenmiş bir zaman dilimi içinde, belirli bir yerleşme alanından dışarıya olan yer değiştirmelerin sayısı" olarak tanımlanır (Tekeli ve Erder, 1978: 62). Daha geniş tanımlamayla göç, belirli dönemlerde sosyo-ekonomik, politik ve kültürel birçok nedene bağlı olarak ulus içinde ve uluslararası alanda bazen zorunlu bazen de gönüllü olarak yapılan mekân değişiklikleridir. Bu mekân değişikliklerinin küreselleştiği ve uluslararası kitlesel göçlere dönüștüğü 19. yüzyılda, bireyler “yurttaş” ve "yabancı” kimlikleri ile kayıt içine alınmaya başlanmış ve bu yüzyıl, bugün uluslararası göç dediğimiz olgunun ortaya çıktığı dönem olarak karşımıza çıkmıştır (Içcduygu, Erder ve Gençkaya, 2014: 13). İşte böyle bir arka plan içinde farklılaşan göçlere bağlı olarak uluslararası göç literatüründe yeni kavramlar ortaya atılmış ve farklı sınıflandırmalar yapılmıştır. Örneğin De Tapia (2002: 17) göç edenleri, mülteciler ve sığınmacılar, sürekli yerleşenler, süreli profesyonel çalışanlar, süreli sözleşmeli işçiler, gizli veya yasadışı çalışanlar şeklinde bir ayrıma giderken; Faist (2003: 47) ise, "sürekli yerleşimciler, geçici sözleşmeli işçiler, geçici meslek misafirleri, gizli ya da illegal işçiler, sığınma hakkı arayanlar ve mülteciler" olarak bir sınıflandırmaya gitmiştir. Günümüzde dünyada ve ülkemizde en çok kullanılan kavramlar ise göçmen, mülteci ve sığınmacı kavramlarıdır. "Göçmen” sözcüğünün uluslararası literatürde tek bir hukuki tanımı yoktur. Bazı yasa yorumcuları, uluslararası kuruluşlar ve medya kuruluşları, bu sözcüğü hem göçmenleri hem de mültecileri kapsayan ortak bir terim olarak kullanmış olsa da, genellikle daha iyi ekonomik fırsatlar aramak için belirli bir sınırı aşan gönüllü göçler kastedilmektedir (IOM, 2020). Bazen de göçmenler aile birleşmesi, eğitim, ekonomik şartlar, doğal felaketlerden dolayı ortaya çıkan aşırı zor şartları azaltma amacıyla da yer değiştirebilirler. Bu zor şartlar nedeniyle göç edenler için uluslararası hukukta mülteci kavramına benzer bir tanımlama yapılmadığı için genel olarak "zorunlu göçmen" olarak tanımlanmaktadır. Oysa savaş, çatışma vb. nedenlerden dolayı ülkelerine dönemeyen ve bu sebeple de uluslararası hukukta özel koruma altına alınan mültecilerin durumu çok daha farklıdır (UNHCR, 2020).

Mülteciler, uluslararası hukukta özel olarak tanımlanmakta ve korunmaktadır. 28 Temmuz 1951 yılında imzalanan ve 22 Nisan 1954 tarihinde yürürlüğe giren Birleşmiş Milletler (BM) Mültecilerin Hukuki Durumuna Dair 
Cenevre Sözleșmesi'nin 1. maddesinde mülteci, “ırkı, dini, tabiiyeti, belli bir gruba mensubiyeti veya siyasi düşünceleri yüzünden, zulme uğrayacağından haklı sebeplerle korktuğu için vatandaşı olduğu ülkenin dışında bulunan ve bu ülkenin korumasından yararlanamayan, ya da söz konusu korku nedeniyle, yararlanmak istenmeyen yahut tabiiyeti yoksa ve bu tür olaylar sonucu önceden yaşadığı ikamet ülkesinin dışında bulunan, oraya dönemeyen veya söz konusu korku nedeniyle dönmek istemeyen her şahıs" olarak tanımlanmaktadır (UNHCR, 2020). Türkiye, 1951 tarihli Cenevre Sözleşmesini, 1. maddesindeki mekân bakımından öngörülen seçme hakkını kullanarak "coğrafi kısıtlama” ile kabul etmiştir. Avrupa dışında meydana gelen olaylar nedeniyle, üçüncü ülkelere iltica etmek üzere mülteci olma koşullarını taşıdığını iddia ederek, Türkiye'den uluslararası koruma talebinde bulunan kişiler ise "şartlı mülteci" olarak kabul edilmektedirler (GiGM, 2020). "Sığınmacı" ise, mülteci statüsü almaya yönelik başvurusu henüz karara bağlanmamış kişiler olarak tanımlanır (IOM, 2013: 74). Diğer taraftan 6458 sayılı yasa kapsamında hukuk mevzuatımıza giren "geçici koruma”, “ülkesinden ayrılmaya zorlanmış, ayrıldığı ülkeye geri dönemeyen, acil ve geçici koruma bulmak amacıyla kitlesel olarak veya bu kitlesel akın döneminde bireysel olarak sınırlarımıza gelen veya sınırlarımızı geçen ve uluslararası koruma talebi bireysel olarak değerlendirmeye alınamayan yabancılara sağlanan koruma” olarak tanımlanır (GiGM, 2020). Genellikle Suriye'deki iç savaştan kaçanlar için hızlı ve pratik uygulama olarak ortaya çıkan geçici koruma ile uluslararası koruma statüsü elde edilmemekte, ancak sınırın açık tutulması, gelenlerin zorla geri gönderilmemesi, cezalandırılmaması, temel ihtiyaçların karşılanmasının yanında sağlığa, eğitime, sosyal yardıma ve iş piyasasına erişim gibi entegrasyon süreçleri sağlanabilmektedir (World Migration Report, 2015: 94).

Kent, insanlar arası ilişkilerin, fiziksel mekâna yansımasının yeni bir boyutu olarak ortaya çıkmıştır (Es ve Ateş, 2004: 211). Keleş'e göre kent, "Sürekli toplumsal gelişme içinde bulunan ve toplumun yerleşme, barınma, gidiş geliş, çalışma, dinlenme, eğlenme gibi gereksinimlerinin karşılandığı, pek az kimsenin tarımla uğraştığı, köylere oranla nüfus yönünden daha yoğun olan ve küçük komşuluk birimlerinden oluşan yerleşme birimidir" (Keleş, 1998: 75). Kent yalnızca, günümüz insanına daha büyük bir oranda iş ve yerleşim olanakları sunan ekonomik amaçlı bir yer değildir; aynı zamanda dünyanın en uzak yerlerini kendine çeken, türlü bölgeleri, insanları ve faaliyetleri bir düzene göre biçimlendiren sosyoekonomik, siyasal ve kültürel yaşamın öncüsü ve denetleyicisi konumunda olan bir merkezdir (Wirth, 2002: 77-78). Bu merkezde, kırsal alanda olmayan hizmetlere ulaşım imkânları olması ve bu imkânlar sayesinde sığınmacıların yaşam standartlarında artış sağlanabilmesi nedeniyle söz konusu yerler, sığınmacılar için çekici olmaktadır (Agblorti, 2011: 76). Dolayısıyla kentler göçün sonlandığı ve sonuçlarının ortaya çıktığı cazibe merkezleri olarak karşımıza çıkmaktadır. Entegrasyon ise, ev sahibi toplum ile göçmen arasındaki karşılıklı uyum olarak tanımlanmaktadır. Bu tanım, göçmenleri ve ev sahibi toplulukları ortak bir amaca 
bağlayan temel değerlere karşı bir yükümlülük ve saygı duygusunu ifade etmek amacıyla kullanılmaktadır (IOM, 2017).

\section{Göç Sonrası Kentte Tutunma ve Entegrasyon}

Toplumsal değişimin ana unsurlarından olan göç eylemiyle, fiziksel bir yer değiştirme olayının yanında maddi ve manevi tüm değerler de göç edilen yerlere taşındığından, söz konusu eylem sonucunda hem göç alan hem de göç veren yerlerde sosyo-ekonomik ve kültürel değişimler yaşanmasının yanında (Castles ve Miller, 2008: 29) çeşitli entegrasyon sorunları da ortaya çıkmaktadır (Aksoy, 2012: 293). Bu sorunlar, genellikle göç edenlerin, kendi yerleşik gelenek ve göreneklerini, tutum ve alışkanlıklarını da beraberlerinde getirdikleri yerlerde kabul ettirme ve dışlanma dikotomisiyle (ikilemiyle) karşı karşıya kalmaları sonucu ortaya çıkmaktadır. Genellikle dışlanılmış bir ortam arz eden gettolarda veya kent çeperlerinde yaşam, yerleşik toplumun hayat tarzlarıyla ilişki kurmasını zorlaştırmakta ve göç edenlerin çoğu iletişim ağı dışında kalmaktadır (BoosNunning, 2007: 206-207). Böylece yerlilerle "çatışma" yaşanmakta ve göç edenler “öteki” haline gelebilmektedir (Chambers, 2014: 106). Diğer bir deyişle göç edenler kendi değerleri ve kültürünü yaşatmaya çalışırken içinde yaşadıkları toplumdan kopmakta, ona ait değerleri ve davranış kalıplarını edinmek bir yana, bunları tanımadan yaşamaya devam etmektedirler (Kymlicka, 2012: 303). Bu nedenle göç edenlerin kentte tutunmaları için sorunların çözümünü sağlayacak iyi bir entegrasyon sürecine ihtiyaç duyulmaktadır. Çünkü ev sahibi toplum ile göçmen arasındaki karşılıklı uyum süreci ekonomik ve kültürel faydalar sağlamanın yanı sıra, toplumların bir bütün olarak güvenlik ve istikrarını sağlamak için de gerekmektedir (IOM, 2017).

Göç sonrası entegrasyonun sağlanması için literatürde birçok yazarın belirlediği yöntemler vardır. Bunlardan Ager ve Strang (2004), John W. Berry (1997) ve Alexandra Fielden'nin (2008) entegrasyon için belirlediği unsurlar bunların önde gelenleridir. İyi ve uyumlu bir entegrasyon için Ager ve Strang, "entegrasyon göstergeleri” adı altında dört başlık altında on maddeden oluşan bir gösterge zinciri ortaya koymuştur. Entegrasyon sürecinde kritik aşamalar olarak görülen barınma, istihdam, eğitim ve sağlık gibi göstergeler göç yönetimini sağlayan kurumlar açısından öncelikli göstergeler olarak kabul edilmektedir. Bu dört göstergeden başka sosyal bağlantılar olarak tanımlanan ve belli bir kategoride sıralanan sosyal köprüler, sosyal bağıntılar ve sosyal bağlar; ikinci aşamada gelen ve aile ve toplum bağlantılarının göç öncesi ve sonrasında yaşadığı erozyonla ilişkilendirilmektedir. Dil ve kültürel bilgi, güvenlik ve istikrar göstergeleri de uyumu daha da kolaylaştırıcı iki etken olarak gösterilmektedir. Entegrasyon süreci için beklentilerin ve yükümlülüklerin dayandığı haklar ve vatandaşlık göstergesi en son sırada yer almaktadır. Ancak birbiri içine girmiş bu göstergelerin birinin diğerinden daha önemli veya bir hiyerarşik yapılanma içinde gösterme yerine bu göstergelerin tamamının birbirleriyle uyumlu bir şekilde 
gerçekleştirilmesine dikkat çekilmiştir (Ager ve Strang, 2004: 2-3). Diğer taraftan Berry (1997: 9), göç edenlerin geçirdiği süreçleri asimilasyon, seperasyon, entegrasyon ve marjinalleşme olarak dört başlık altında toplamaktadır. Bireyler kültürel kimliğini korumak ve bunun için diğer kültürlerle etkileşimde bulunmak istemiyorsa asimilasyon; bireylerin özgün kültürlerini korumaya değer verdikleri ve aynı zamanda başkalarıyla etkileşim kurmaktan kaçınmak istediğinde seperasyon; hem diğer gruplarla günlük etkileşimde bulunmak hem de kendi orijinal kültürünün korunmasına ilgi duyulduğunda entegrasyon ve son olarak, kültürel korumaya (genellikle zorla uygulanan kültürel kayıplar sebebiyle) ve toplumsal değerlerle (çoğunlukla dışlanma veya ayrımcılık sebepleri nedeniyle) ilişki kurma konusunda az ilgi olması durumunda marjinalleşme olarak ortaya çıkmaktadır.

Kente göç edenlerin entegrasyonun sağlanması için Fielden'in (2008: 1) hazırladığı raporda üç tür entegrasyon boyutundan bahsedilmektedir. Birincisi, mülteci veya sığınmacıların vardığı ülkede yasal bir statüsünün olmasıdır. İkincisi, ev sahibi toplumla benzer yaşam standartları için sürdürülebilir geçim kaynaklarının sağlanmasına destek olunmasıdır. Son olarak mültecilerin veya sığınmacıların ev sahibi toplumun sosyal yaşamına katkıda bulunmasını ve ayrımcılık korkusu olmadan yaşamasını sağlayan sosyal ve kültürel bir sürecin ortaya konulmasıdır. Göç edenlerin ülke içinde hangi statüde yer alacağı entegrasyon süreçleri açısından hayati önem taşımaktadır. Ülkemizde özellikle Suriyeli sığınmacılar göçünde mevzuat açısından statü karmaşası ortaya çıkmış ve gelenlerin hangi statüde yer alacağı tartışma konusu olmuştu. Bu sorunun büyümesi nedeniyle Türkiye, 1951 Cenevre Sözleşmesi'ne koyduğu çekince ve kendi iç mevzuatı gereğince Suriyelileri mülteci statüsünde kabul etmemiş, sınırlarını açık kapı politikasıyla Suriyelilere açmış ve mevcut uygulamaların dışına çıkmıştır (iç̧duygu ve Aksel, 2013: 182). Böylece uluslararası hukukta geçen "geri göndermeme" ilkesine de uyarak vatandaşlık dışında sağlık, barınma, istihdam, eğitim ve diğer ihtiyaçları karşılama noktasında girişimlerini arttırmıştır (Kirişçi ve Karaca, 2015: 301-309). Ancak 2015 yilından itibaren misafir olmanın ötesine geçen sığınmacılara ilişkin Türkiye'nin göç politikası değişim göstermiş ve geçici kabul aşamasından çıkarak yerleşim (2013-2015), entegrasyon (2016 boyunca) ve potansiyel olarak vatandaşığa geçme dönemine doğru eğilim göstermiştir (içcuygu ve Millet, 2016: 4; Elitok, 2019: 1). Böylece sosyal yaşamın her alanına uyum sağlamaları için Fielden'in belirlediği üç boyut tam olarak olmasa da başta 04/04/2013 tarihli ve 6458 sayılı Yabancılar ve Uluslararası Koruma Kanunu, 22 Ekim 2014 tarihli Geçici Koruma Yönetmeliği ve bu mevzuat çerçevesinde kurulan Göç Idaresi Genel Müdürlüğü'nün hayata geçirilmesi ile daha insani ve hak temelli adımların atıldığı söylenebilir.

\section{Saha Çalışmasının Değerlendirilmesi}

Bu bölüm, 2011-2020 yılları arasında göç eden Suriyeli sığınmacıların entegrasyon sürecini ve gelecek beklentilerini tespit etmek amacıyla Batman'da 
yapılan saha çalışmasına ait bulguların değerlendirilmesini içerir. Bulgular, verilenlerin yorumlanması, değerlendirilmesi ve öneriler sunulması şeklinde analiz edilmiştir.

\section{Araștırma Alanının Kısa Özellikleri}

Tarihi M.Ö. 546 yılına dayanan ve bulunduğu Batman suyu ile Botan suyu arasında kalan bölgeden ismini alan Batman, Elah, Elekhan ve son olarak Illuh adıyla Siirt vilayeti El-medine kazasına bağlı bir köy olarak 1950'lere kadar varlığını sürdürmüștür (Türk, 2020a: 78). Batman, köy statüsünde bulunduğu bu döneme kadar köy nüfusu binin altında kalmıştı (Tuncel, 1992: 201). Ancak 1940'li yılların başlarında bölgede bulunan petrol rezervlerinin değerlendirilmesi sonucunda sanayileşmeye bağlı artan iç göçlerle önemli bir kente dönüşmüştür. 1955'te yapılan genel nüfus sayımında, Batman'ın nüfusu 4713 kişi olarak dünyada nüfusu en çok artan yerleşim yerlerinden biri olarak kaydedilmiştir. Artan nüfusa bağlı olarak 2 Kasım 1955'te "belediye”, 2 Eylül 1957 tarihinde “ilçe” teşkilatı kurulmuştur. Batman olarak asıl ismini yakından geçen Batman çayı ile bütünleşmesine bağlı olarak bu yıllarda almıştır (Çoban, Dilek ve Harman, 2017: 439). 1990 yılına kadar hızlı bir gelișme gösteren Batman, 16 Mayıs 1990 tarih ve 3647 sayılı yasa ile Türkiye'nin 72. ili olmuştur (Kaypak ve Bimay, 2016: 95-97). Bu gün merkez nüfusu 460,955 ve toplam nüfusu 599,103 olarak belirlenen Batman, zaman zaman iç ve dış göçlere de maruz kalmıştır (TÜiK, 2019). 1990’lara kadar sürekli olarak iç göçlerle büyüyen Batman, bu dönemden sonra İran-Irak Savaşı, 1. ve 2 . Körfez Harbi nedeniyle savaştan kaçan Kürtlere ve günümüzde Suriye'deki iç çatışmalarından kaçan Kürt ve Arap sığınmacılara ev sahipliği yapmıștır. Bu gün Batman'da 15.492 (nüfusun \%2,55) Suriyeli sığınmacı barınmaktadır (GiGM, 2020).

\section{Araștırmanın Amacı, Kapsamı ve Sınırlılıkları}

Bu çalışmanın amacı, son on yılda Batman kent merkezine göç eden Suriyeli sığınmacıların entegrasyon süreci ve gelecek beklentilerine ilişkin yaşanan olumlu ve olumsuz yanların ortaya çıkartılarak bu konuda üretilecek politikalara destek sunmaktır. Diğer bir deyişle, Batman'a yapılacak yeni göçlerin etkilerinin önceden tahmin edilerek entegrasyon süreçlerinin iyi yönetilmesine katkı sağlaması amaçlanmaktadır. Bu kapsamda araştırmanın hedef evrenini oluşturan 15.492 Suriyeli sığınmacıdan anketlere yanıt vermek isteyen 18 yaşından büyük toplam 134 sığınmacıya 29 sorudan oluşan anket uygulanmıştır. Anketler, 2020 yılının Mayıs ve Haziran aylarında yapılmıştır.

Araştırmanın kapsamı, kaynak ve sürenin kısıtlılığı nedeniyle Batman'da bulunan Suriyeli sığınmacılarla sınırlı tutulmuştur. Diğger taraftan Batman'da yaşayan 18 yaşından büyük sığınmacılara ulaşmada zorluklar, kadın sığınmacıların çekingen davranması, sığınmacıların Türkçe bilmemeleri nedeniyle kendileriyle 
ancak Arapça ve Kürtçe tercümanlar aracılığıyla iletişim kurulabilmesi ve koronavirüs (KOVID-19) salgını gibi olaylar yüz yüze anket yapmayı zorlaştırmıştır.

\section{Araștırmanın Yöntemi}

Araştırmada, Batman'da yaşayan Suriyelilerin sosyo-ekonomik ve kültürel açıdan entegrasyon sorunu yaşadıkları ve gelecek beklentileriyle ilgili karamsar bir durumun ortaya çıktığı ana beklentisinden hareket edilmiştir. Buradan hareketle yapılan araştırma için geliştirilen yöntem ise, değişkenlerin ölçümlerinin sayıyla ifade edilmesini sağlayan nicel araştırma yöntemidir (Punch, 2011). Bu bağlamda, Batman'da yaşayan ve araştırmanın çalışma evrenini (ana kütle) oluşturan toplam 15.492 Suriyeli sığınmacı içinden anketi yanıtlamak isteyen 18 yaş üstü 134 kişilik örnek kütle seçimi yapılmış ve yüz yüze anket gerçekleştirilmiştir. Anketler, Batman Üniversitesi Etik Kurulu'nun 13.05.2020 tarih ve E. 8397 sayılı onayıyla 2020 yılının Mayıs ve Haziran aylarında yüz yüze görüşmeler şeklinde uygulanmıştır. Anket yoluyla elde edilen bulguların betimsel veya tanımlayıcı istatistikleri SPSS 24 programı aracılı̆̆ıyla yapılarak frekans ve yüzde dağılımları şeklinde analiz edilmiş ve yorumlanmıştır.

\section{Bulgular}

Bu bölümde, Batman kent merkezinde yapılan saha araştırmasından elde edilen bulguların betimsel veya tanımlayıcı istatistiklerine ilişkin değerlendirmeler yer almaktadır.

Tablo 1. Katılımcıların Cinsiyetine Göre Dağılımı

\begin{tabular}{lll}
\hline Değişkenler & $F$ & $\%$ \\
\hline Erkek & 71 & 53,0 \\
Kadın & 63 & 47,0 \\
Toplam & 134 & 100,0 \\
\hline
\end{tabular}

Katılımcıların 71’i (\%53) erkek, 63’ü (\%47) ise kadınlardan oluşmaktadır. Mülakat boyunca erkeklerin oranı kısmen fazla olmasına rağmen kadın katılımcılarının oranının da beklenenin üstünde olduğu ortaya çıkmaktadır. Yapılan araştırmalarda kadın sığınmacıların genel olarak anketli mülakatlara yanıt vermekten kaçınmalarına rağmen anketörlerin özellikle kadınlardan seçilmesi ve söz konusu anketörlerin Arapça bilmeleri kadın katılımcı sayısının artmasını sağlamıştır. 
Tablo 2. Katılımcıların Yașlarına Göre Dağılımı

\begin{tabular}{lll}
\hline Değişkenler & $F$ & $\%$ \\
\hline $18-28$ & 26 & 19,4 \\
$29-39$ & 52 & 38,8 \\
$40-50$ & 37 & 27,6 \\
$51-51$ & 12 & 9,0 \\
$62+$ & 7 & 5,2 \\
Toplam & 134 & 100,0 \\
\hline
\end{tabular}

Katılımcıların çoğunluğu gençlerden oluşurken, bunların 52'si $(\% 38,8)$ 29-39 yaş aralığında olanlar olduğu ortaya çıkmıştır. Genç katılımcıların fazla olmasını, bu yaş grubundakilerin mülakat yapmaya daha istekli olmaları ve eğitim düzeylerinin de yüksek olmasına bağlanabilir.

Tablo 3. Katılımcıların Medeni Durumlarına Göre Dağılımı

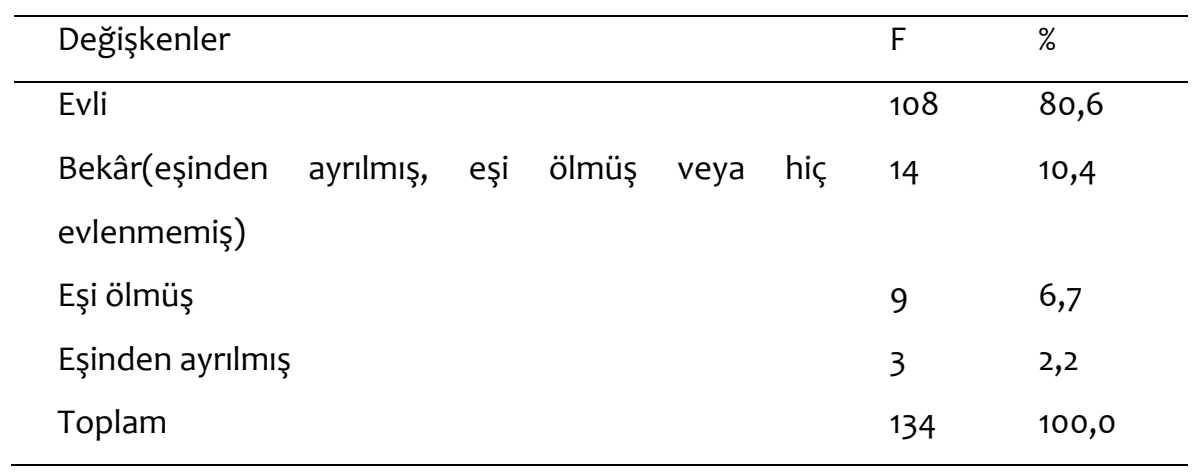

Kişiler göç ederken genel olarak sonraki hayatlarını da eşleri ve çocuklarıyla beraber devam etmek isterler. Doğal olarak Suriye'den kaçan sığınmacıların büyük çoğunluğu $(\% 80,6)$ evli iken genellikle savaşta eşini kaybederek çocuklarıyla gelenlerin sayısı ise $9(\% 6,7)$ kişi olarak tespit edilmiştir.

Tablo 4. Katılımcıların Eğitim Durumuna Göre Dağılımı

\begin{tabular}{lll}
\hline Değişkenler & $F$ & $\%$ \\
\hline Okur-yazar değil & 30 & 22,4 \\
Ilkokul Mezunu & 13 & 9,7 \\
Ortaokul Mezunu & 34 & 25,4 \\
Lise Mezunu & 33 & 24,6
\end{tabular}


Ön Lisans veya Lisans Mezunu

Yüksek lisans veya Doktora Mezunu

Toplam
16

8

134
11,9

6,0

100,0

Eğitim durumlarına bakıldığında katılımcıların çoğunluğu belli bir eğitim düzeyine sahip iken, okur-yazar olmayanların oranın yüksek olduğu görülmektedir. Buna göre katılımcıların 30'ü $(\% 22,4)$ okur-yazar olmayan, 13 'ü $(\% 9,7)$ ilkokul mezunu, 34'ü $(\% 25,4)$ ortaokul mezunu, 33’ü $(\% 24,6)$ lise mezunu, 24 'ü $(\% 15,5)$ lisans veya lisansüstü mezunu olarak tespit edilmiştir. Herhangi bir üniversiteden mezun olanların oranı Türkiye'deki sığınmacı profilinin üstünde görülmektedir.

Tablo 5. Katılımcıların Geldiği Kentlere Göre Dağılımı

\begin{tabular}{lll}
\hline Değişkenler & $F$ & $\%$ \\
\hline Halep & 43 & 32,1 \\
İdlip & 16 & 11,9 \\
Rakka & 5 & 3,7 \\
Hama & 3 & 2,2 \\
Şam & 11 & 8,2 \\
Haseki & 48 & 35,8 \\
Diğer & 8 & 6,0 \\
Toplam & 134 & 100,0 \\
\hline
\end{tabular}

Savaş vb. nedenlerle göç eden sığınmacılar genellikle en yakın ülke ve kentlere göç etmeye çalışmaktadırlar. Bu nedenle Batman'a gelen sığınmacılardan 48 'i $(\% 35,3)$ en yakın Suriye kenti Haseki, 43'ü $(\% 32,1)$ Halep iken geri kalanların 16 'sı $(\% 11,9)$ İdlib, 11'i $(\% 8,2)$ Şam, 5'i $(\% 3,7)$ Rakka ve 11 'i $(\% 8,2)$ ise Hama, Menbic, Deyrezzor gibi diğer kentlerden gelmişlerdir.

Tablo 6. Katılımcıların Geldiği Yıllara Göre Dağııımı

\begin{tabular}{lll}
\hline Değişkenler & $F$ & $\%$ \\
\hline $2019-2020$ & 2 & 1,5 \\
2018 & 5 & 3,7 \\
2017 & 8 & 6,0 \\
2016 & 20 & 14,9
\end{tabular}


100,0

Geldikleri yıllara bakıldığında Batman'a gelen sığınmacıların çoğunluğu (\% 88,8) 2016 yilı ve öncesinde göç etmişlerdir. Geri kalanlar ise 2017 ve sonrası gelenlerdir. Dolayısıyla son yıllarda Batman'a gelen sığınmacı sayısında azalma olduğu ortaya çıkmıştır. Bunun nedeni olarak ilk dönemlerde savaşın Haseki, Halepçe gibi Batman'a yakın kentlerde yoğunlaştığı, sonraki dönemlerde ise bu yoğunluğun İdlip gibi uzak kentlere kayması olarak söylenebilir.

Tablo 7. Katılımcıların Türkiye'yi Göç Ülkesi Olarak Tercih Etme Nedenine Göre Dağılımı

\begin{tabular}{lcc}
\hline Değişkenler & $\mathrm{F}$ & $\%$ \\
\hline Daha güvenli olması & 41 & 30,6 \\
En yakın ülke olması & 47 & 35,1 \\
Gelişmişlik düzeyi & 14 & 10,4 \\
Başka seçeneğim olmaması & 11 & 8,2 \\
Akrabalarımın veya tanıdıklarımın önerisi üzerine & 13 & 9,7 \\
Diğer & 8 & 6,0 \\
Toplam & 134 & 100,0 \\
\hline
\end{tabular}

Savaş vb. zorunlu nedenlerle göç eden sığınmacıların göç ettikleri ilk mekânlar genel olarak kendilerine en yakın ve en güvenli ülkelerin sınır kentleri oluşmaktadır. Katılımcıların 86'sı $(\% 65,8)$ Türkiye'yi göç ülkesi seçmelerinin sebebi olarak yakınlık ve güvenlik seçeneklerini öne sürmüşlerdir. Diğer taraftan sığınmacıların 14'ü $(\% 10,4)$ Türkiye'nin diğer komşu ülkelere göre daha gelişmiş olmasını ön plana çıkartmışlardır. Suriyeli sığınmacıların göçünde akraba ve tanıdıkların göç üzerindeki etkisinin genel oran içinde düşük olması $(\% 9,7)$ "Ağ Kuramı" ile ifade edilen ve göç etme kararları üzerinde ağların etkisinin olduğunu (Kurekova, 2011) ileri süren varsayımı zayıflatmaktadır. 
Tablo 8. Katılımcıların Batman'da İkamet Ettiği Mekân Türüne Göre Dağılımı

\begin{tabular}{lll}
\hline Değişkenler & $\mathrm{F}$ & $\%$ \\
\hline Kiralık ev & 112 & 83,6 \\
Çadır & 7 & 5,2 \\
Kendi evi & 12 & 9,0 \\
Başka aileyle & 3 & 2,2 \\
Toplam & 134 & 100,0 \\
\hline
\end{tabular}

Katılımcıların 106'sı $(\% 79,1)$ kiralık evde yaşadıklarını belirtmişlerdir. Geri kalanların çadırda, kendi evlerinde ve başka ailelerle yaşadıkları söylenebilir. Buradan hareketle gelir durumunun düşük olmasına bağlı olarak genel olarak sığınmacıların kirada oturmak zorunda kaldıkları anlaşılmaktadır.

Tablo 9. İkamet Edilen Yerde Yaşayan Kiși Sayısına Göre Dağııımı

\begin{tabular}{lll}
\hline Değişkenler & $F$ & $\%$ \\
\hline $1-3$ & 12 & 9,0 \\
$4-6$ & 59 & 44,0 \\
$7-10$ & 46 & 34,3 \\
$10+$ & 17 & 12,7 \\
Toplam & 134 & 100,0 \\
\hline
\end{tabular}

Aynı evde yaşayanların sayısı açısından katılımcıların 122'si (\%91) diğer bir deyişle tamamına yakını dörtten fazla kişi ile yaşadığını belirtmiştir. Suriyeli sığınmacıların çok kalabalık yaşadıkları ve bunların önemli oranın çocuklardan oluştuğu tespit edilmiştir. Bu da iş imkânlarının sınırlılığı, iş hayatında tutunamama, açık sınırında yaşam şartları gibi ekonomik ve sosyal ilişkiler açısından sorunlar yaşamalarına neden olabilmektedir.

Tablo 10. Katılımcıların Geçimini Sağlama Biçimine Göre Dağılımı

\begin{tabular}{lll}
\hline Değișkenler & $F$ & $\%$ \\
\hline Herhangi bir işte çalışarak & 80 & 59,7 \\
AFAD & 23 & 17,2 \\
Vakıf/Dernek & 4 & 3,0 \\
Halk yardımı & 13 & 9,7 \\
Birikim & 1 &, 7
\end{tabular}




$\begin{array}{lll}\text { Diğer } & 13 & 9,7 \\ \text { Toplam } & 134 & 100,0\end{array}$

Katılımcıların yarısından fazlası $(\% 59,7)$ herhangi bir işte çalışarak geçimlerini sağladıkları ortaya çıkmıştır. Geri kalanların önemli bir bölümü AFAD desteğinden yararlanırken, diğerleri halkın yardımı, STK, kendi birikimleri ve diğer yardımlardan yararlanarak geçimlerini sağladıkları tespit edilmiştir. Dolayısıyla sığınmacıların kalma süresi uzadıkça çalışma imkânlarının da arttığı görülmektedir. Yine de çeşitli kurum ve kuruluşlardan yardım alanlarında katılımcıların üçte birine denk gelmesi ekonomik anlamda entegrasyon sorunu yaşandığını ortaya koymaktadır.

Tablo 11. Katılımcıların Türkiye'de Çalıștığı İş Alanlarına Göre Dağılımı

\begin{tabular}{lll}
\hline Değişkenler & $F$ & $\%$ \\
\hline Serbest iş (doktor, avukat, muhasebeci, hırdavatçı, & 55 & 41,0 \\
eskici vd.) & & \\
Esnaf yanında & 11 & 8,2 \\
İnşaat & 29 & 21,6 \\
Oto sanayi-OSB & 3 & 2,2 \\
Diğer(Ev hanımı vb.) & 36 & 26,9 \\
Toplam & 134 & 100,0 \\
\hline
\end{tabular}

Katılımcıların göç ettikten sonra çalıştığı iş alanlarına bakıldığında 57'si $(\% 40,7)$ hırdavatçı, eskici, boyacı, ev işleri yapan ve nadirde olsa doktorluk, avukatlık, muhasebecilik gibi serbest işlerde çalışanlardan olduğu ortaya çıkmıştır. Geri kalanların 29'u $(\% 20,7)$ inşaatlarda, 11'i $(\% 8,2)$ esnafın yanında, 36'si $(\% 26,9)$ ise ev hanımı ya da çalışmayanlardan oluşmaktadır.

Tablo 12. Katılımcıların Türkiye'de Yaptıkları İșten Elde Ettikleri Aylık Gelirlere Dağılımı (Türk Lirası)

\begin{tabular}{lll}
\hline Değişkenler & $F$ & $\%$ \\
\hline $0-500$ & 34 & 25,4 \\
$501-1000$ & 30 & 22,4 \\
$1001-1500$ & 20 & 14,9 \\
$1501-2000$ & 20 & 14,9 \\
$2000+$ & 16 & 11,9
\end{tabular}


Toplam

Geliri durumunu belirtmeyenler

Genel Toplam
120

14

134
89,6

10,4

100,0

Göç ettikten sonraki gelir durumlarına bakıldığında gelir durumunu belirtmekten kaçınanların $(\% 10,4)$ dışında genel olarak gelir düzeylerinin düşük olduğu ve hatta açlık sınırının altında bir gelire sahip olanların çoğunlukta olduğu ortaya çıkmıştır. Sığınmacıların 34'ü $(\% 25,4) 500$ TL'nin altında gelir elde ederken, 70 ’i $(\% 52,2)$ asgari ücretin altında bir rakam olan 500 TL ile 2000 TL arasında bir gelir elde ettikleri tablodan anlaşılmaktadır. Batman'da sanayi ve ticaretin gelişimine bağlı olarak 2000 TL ve üzeri gelir elde edenlerin oranı ise \%11.9 civarında kalmıştır. Buradan hareketle sığınmacıların on yıllık süre zarfında ekonomik açıdan entegrasyonu gerçekleştiremedikleri ortaya çıkmaktadır.

Tablo 13. Katılımcıların Türkiye'de Karşılaştıkları En Önemli Soruna Göre Dağııımı

\begin{tabular}{lcc}
\hline Değişkenler & $F$ & $\%$ \\
\hline Barınma & 6 & 4,5 \\
Beslenme & 8 & 6,0 \\
İkamet tezkeresi & 8 & 6,0 \\
Sağlık & 5 & 3,7 \\
Eğitim & 2 & 1,4 \\
Dil & 36 & 26,9 \\
İş bulamama & 11 & 8,2 \\
Ayrımcılık & 7 & 5,2 \\
Düşük iş ücreti & 13 & 9,7 \\
Yüksek kira & 31 & 23,1 \\
Diğer & 7 & 5,2 \\
Toplam & 134 & 100,0 \\
\hline
\end{tabular}

Katılımcılara göç edildikten sonra “Türkiye'de karşılaştığınız en önemli sorun nedir?" Sorusuna verilen ifadelerde doğal olarak dil sorunu $(\% 26,9)$ karşımıza çıkmaktadır. Geri kalanlardan 31’i $(\% 23,1)$ yüksek kira, 13’ü $(\% 9,7)$ düşük iş ücreti, 11'i $(\% 8,2)$ iş bulamama, 8'i (\%6) beslenme, 8'i (\%56) ikamet tezkeresi, 7'si 
$(\% 5,2)$ ayrımclık, geri kalanı ise barınma $(\% 4,5)$, sağlık $(\% 3,7)$ ve diğer sorunları belirtmişlerdir. Dil sorunu dışında genel olarak ekonomik sorunların ön plana çıktığı tablodan anlaşılmaktadır. Batman'da genel olarak inşaat sektörünün geliştiği, ancak iç göçlerinin yanında dış göçlerle artan nüfusun ihtiyacını karşılamaktan uzak olması nedeniyle kiralarda artış ortaya çıktığı varsayılmaktadır.

Tablo 14. Katıımcıların Barınma ile ilgili Yaşadıkları Sorunlara Göre Dağılımı

\begin{tabular}{lcc}
\hline Değişkenler & $F$ & $\%$ \\
\hline Kalacak yerim yok & 7 & 5,2 \\
Kaldığım yer havasız & 14 & 10,4 \\
Kaldığım yer kirli & 1 &, 7 \\
Isınma -soğutma sorunu var & 13 & 9,7 \\
Aydınlatma sorunu var & 1 &, 7 \\
Kaldığım yer kalabalık & 11 & 8,2 \\
Yüksek kira ücretleri & 73 & 54,5 \\
Toplam(Sorun yaşayanlar) & 120 & 89,6 \\
Sorun yaşamayanlar & 14 & 10,4 \\
Genel Toplam & 134 & 100,0 \\
\hline
\end{tabular}

Entegrasyon süreçlerinin en önemli boyutlarından bir tanesi de barınmadır. Katııımcılara barınma ile ilgili sorun yaşayıp yaşamadıklarına ilişkin soruya 120'si $(\% 89,6)$ sorun yaşadıklarını belirtmişlerdir. Barınma sorunlarında sığınmacıların yarısından fazlası $(\% 54,5)$ yüksek kira ücretlerinden yakındıkları ortaya çıkmıştır. Diğer barınma sorunları ise sırasıyla kaldıkları yerin havasız olması, kalabalık olması ve ısıtma ve soğutma sorunları olarak belirtilmiştir. Dolayısıyla gelir düzeyleri düşük olan ve iş bulup da çalışanlarında düşük ücretlerle çalıştıkları düşünüldüğünde Tablo 13'da ve Tablo 14'den anlaşıldığı üzere yüksek kiralardan kaynaklanan önemli bir barınma sorunu olduğu ortaya çıkmıştır.

Tablo 15. Katılımcıların Beslenme Ille ilgili Yaşadıkları Sorunlara Göre Dağılımı

\begin{tabular}{lcc}
\hline Değişkenler & $F$ & $\%$ \\
\hline Her gün kahvaltı yapamıyorum & 21 & 15,7 \\
Her gün öğle yemeği yiyemiyorum & 11 & 8,2
\end{tabular}


Her gün akşam yemeği yiyemiyorum

129,0

Bebekler için süt/mama temin edemiyorum

$19 \quad 14,2$

Et yiyemiyorum

2216,4

Tatlı veya çerez yiyemiyorum

139,7

Toplam(Sorun yaşayanlar)

$98 \quad 73,1$

Sorun yaşamayanlar

$36 \quad 26,9$

Genel Toplam

134100,0

Sığınmacıların göç ettikleri ilk dönemlerde yerelde entegrasyonun ilk ayağını beslenme oluşturmaktadır. Ancak gelinen süreçte katılımcıların çoğunun $(\% 73,1)$ beslenme sorunu yaşadığını belirtmesi, önemli bir entegrasyon sorunu olarak karşımıza çıkmaktadır. Özellikle bazı öğünlerde yemek yenilememesi bu sorunun ciddiyetini ortaya koymaktadır.

Tablo 16. Katılımcıların Sağlıkla ile Illgili Yaşadıkları Sorunlara Göre Dağıımı

\begin{tabular}{lcc}
\hline Değişkenler & F & $\%$ \\
\hline Doktorlar ilgisiz & 17 & 12,7 \\
Ebe -Hemşire ilgisiz & 5 & 3,7 \\
Dil problemi yaşıyorum & 43 & 32,1 \\
Tedavi masraflarını karşılayamıyorum & 23 & 17,2 \\
Illaç alamıyorum & 13 & 9,7 \\
Hastaneler tedavi etmiyor & 9 & 6,7 \\
Toplam(Sorun yaşayanlar) & 110 & 82,1 \\
Sorun yaşamayanlar & 24 & 17,9 \\
Genel Toplam & 134 & 100,0 \\
\hline
\end{tabular}

Katılımcılara yöneltilen sağlıkla ile ilgili sorun yaşayıp yaşamadıklarına ilişkin soruya 110'u (\%82,1) sorun yaşadıklarını belirtmiştir. Sağlık sorunlarının başında dil problemi $(\% 32,1)$ gelirken, geri kalanlardan 23 'ü $(\% 17,2)$ ekonomik sebeplerle tedavi masraflarını karşılayamadığını, 17'si $(\% 12,7)$ doktorların ilgisiz olduğunu, 13'ü $(\% 9,7)$ 
ilaç alamadığını diğerleri $(\% 10,4)$ hastanelerden ve hemşirelerin ilgisizliğinden yakınmışlardır. Dolayısıyla dil ve ekonomik imkanlar sağlık sorunlarında da ön plana çıkmaktadır.

Tablo 17. Katılımcıların Eğitim ile İlgili Yaşadıkları Sorunlara Göre Dağılımı

\begin{tabular}{lll}
\hline Değişkenler & F & $\%$ \\
\hline Dil problemi var & 64 & 47,8 \\
Defter, kitap alamıyorum & 20 & 14,9 \\
Çocuğum okula gidemiyor & 7 & 5,2 \\
Okula devam etmem için gerekli belgeler Suriye'de kalmış & 3 & 2,2 \\
Çocuğum okul arkadaşlarıyla uyum sorunu yaşıyor & 12 & 9,0 \\
Toplam(Sorun yaşayanlar) & 106 & 79,1 \\
Sorun yaşamayanlar & 28 & 20,9 \\
Genel Toplam & 134 & 100,0 \\
\hline
\end{tabular}

Sığınmacıların sığındıkları ülkede eğitimlerine devam etmeleri entegrasyonlarında hayati önem taşımaktadır. Katılımcılara eğitim ile ilgili sorun yaşayıp yaşamadıklarına ilişkin soruya 106'sı $(\% 79,1)$ sorun yaşadıklarını belirtmiştir. Eğitim sorunlarında sığınmacıların 64'ü $(\% 47,8)$ dil problemi yüzünden eğitim sorunu yaşadığını, geri kalanlardan 20'si $(\% 14,9)$ ekonomik sebeplerle defter ve kitap alamadığını, 12'si $(\% 9,0)$ çocuklarının okul arkadaşlarıyla sorunlar yaşadıklarını belirtmişlerdir. Dolayısıyla dil ve ekonomik imkanlar eğitim sorunlarında da karşımıza çıkmaktadır.

Tablo 18. Katılımcıların İş Bulma ile İlgili Yaşadıkları Sorunlara Göre Dağılımı

\begin{tabular}{llc}
\hline Değişkenler & $F$ & $\%$ \\
\hline İş bulamıyorum & 50 & 37,3 \\
Suriyeli olduğum için düşük ücret veriyorlar & 44 & 32,8 \\
Çalışıyorum ama maaşımı alamıyorum & 2 & 1,5 \\
Resmi olarak çalışamıyorum & 11 & 8,2 \\
Şirket kuramıyorum & 9 & 6,7 \\
İş yerinde patron ya da arkadaşlarım tarafından haksızlığa & 2 & 1,5 \\
Toplam(Sorun yaşayanlar) & 118 & 88,1
\end{tabular}


Sorun yaşamayanlar

Genel Toplam
16

134100,0

Katılımcılara çalışma hayatı ile ilgili sorun yaşayıp yaşamadıklarına ilişkin yöneltilen soruya cevaben, katılımcıların 118 'i $(\% 88,1)$ sorun yaşadıklarını belirtmiştir. Çalışma hayatında yaşanan sorunlara ilişkin olarak sığınmacıların 50'si $(\% 37,3)$ iş bulamadığını, 44'ü $(\% 32,8)$ Suriyeli olduğu için düşük ücret verildiğini, 11’i $(\% 8,2)$ resmi olarak çalışmadığını, geri kalanı ise şirket kuramadıklarını, iş yerinde patron ya da arkadaşları tarafından haksızlığa uğradığını belirtmişlerdir.

Tablo 19. Katılımcıların Dil ille İlgili Yaşadıkları Sorunlara Göre Dağılımı

\begin{tabular}{|l|l|l|}
\hline Değişkenler & F & $\%$ \\
\hline Okula gidemiyorum & 14 & 10,4 \\
\hline Resmi dairelerde derdimi anlatamıyorum & 31 & 23,1 \\
\hline Dersleri anlamakta zorlanıyorum & 18 & 13,4 \\
\hline Türkçe bilmediğim için dışlanıyorum & 17 & 12,7 \\
\hline Farklı dilde konuştuğum için insanların dikkatini çekiyorum & 39 & 29,1 \\
\hline Toplam (Sorun yaşayanlar) & 119 & 88,8 \\
\hline Sorun yaşamayanlar & 15 & 11,2 \\
\hline Genel Toplam & 134 & 100,0 \\
\hline
\end{tabular}

Sığınmacıların entegrasyonunda ev sahibi ülkenin ana dilinin bilinmesi iş ve sosyal hayatta önemli kolaylıklar sağlamaktadır. Katılımcılara yöneltilen dil sorunu yaşayıp yaşamadıklarına ilişkin soruya cevaben, katılımcıların 119 'u $(\% 88,8)$ sorun yaşadıklarını belirtmiştir. Sığınmacıların 39'u (\%29,1) farklı dilde konuştukları için başkalarının dikkatini çektiğini, 31'i $(\% 23,1)$ resmi dairelerde derdini anlatamadığını, 18'i $(\% 13,4)$ aldıkları Türkçe derslerini anlayamadıklarını, 17’si $(\% 12,7)$ Türkçe konuşamadığı için dışlandığını, 14’ü $(\% 10,4)$ okula gidemediğini belirtmiştir.

Tablo 20. Katılımcıların íkamet Tezkeresi ile ilgili Yaşadıkları Sorunlara Göre Dağılımı

\begin{tabular}{llc}
\hline Değiş̧kenler & $F$ & $\%$ \\
\hline Nasıl ve nereden alınacağını bilmiyorum & 23 & 17,2
\end{tabular}


Onuncu Yılında Suriyeli Sığınmacıların Kente Entegrasyonu ve Gelecek Beklentileri: Batman

Harç miktarı yüksek

Ödemelerde kolaylık sağlamıyorlar

129,0

Toplam(Sorun yaşayanlar)

$77 \quad 57,5$

Sorun yaşamayanlar

$57 \quad 42,5$

Genel Toplam

134100,0

Katılımcılara ikamet tezkeresi ile ilgili sorun yaşayıp yaşamadıklarına ilişkin soru yöneltilmiş ve katılımcıların 77 'si $(\% 57,5)$ sorun yaşadıklarını belirtmiştir. Sorun yaşayan sığınmacıların 42'si $(\% 31,3)$ harç miktarının yüksek olması nedeniyle bașvuramadığını, 23'ü $(\% 17,2)$ nasıl ve nereden alınacağını bilmediği için başvuramadığını, geri kalanlarda $(\% 9,0)$ ödemelerde kolaylık sağlanamadığından başvuru imkanının olamadığını belirtmiştir.

Tablo 21. Katılımcıların Türkiye'de Sosyal Ve Kültürel Aktivitelere Katılma Durumuna Göre Dağılımı

\begin{tabular}{llc}
\hline Değișkenler & F & \\
\hline Evet & 28 & 20,9 \\
& & \\
Hayır & 106 & 79,1 \\
& & \\
Toplam & 134 & 100,0
\end{tabular}

Katılımcılara Türkiye'de sinema, tiyatro ve spor gibi sosyal ve kültürel aktivitelere katılıp katılmadıkları sorulmuş, sığınmacıların büyük çoğunluğu $(\% 79,1)$ hiçbir aktiviteye katılmadığını belirtmiştir. Dolayısıyla belli bir ekonomik ve eğitim düzeyine sahip olmayan birinin önceliğinin kültürel faaliyetler olması beklenemez. Maslow'un hedeflere ulaşmada ve kendini gerçekleştirmede ortaya koyduğu "ihtiyaçlar hiyerarşisi” teorisiyle hayatta daha üst düzeyde sosyal hedeflerin ortaya çıkabilmesinin bir üst seviyedeki fizyolojik ihtiyacın karşılanmasına bağlı olduğu (Walsh, 2011: 791) tezi, Batman'daki Suriyelilerin yaşamında da karşımıza çıkmaktadır. 
Tablo 22. Katılımcıların Türkiye'de Güncel Olayları Takip Etme Durumuna Göre Dağılımı

\begin{tabular}{lcc}
\hline Değişkenler & $F$ & $\%$ \\
\hline Gazete & 6 & 4,5 \\
Televizyon & 79 & 59,0 \\
Internet & 45 & 33,6 \\
Diğer & 4 & 3,0 \\
Toplam & 134 & 100,0 \\
\hline
\end{tabular}

Katılımcılara Türkiye'de güncel olayları nasıl takip ettikleri sorulmuş, sığınmacıların yarısından fazlasının $(\% 59,0)$ güncel olayları televizyondan takip ettikleri ortaya çıkmıştır. Geri kalanların 45'inin $(\% 33,6)$ güncel olayları internet, 10'unun $(\% 7,5)$ gazete ve diğer kişilerden takip ettikleri ortaya çıkmıştır. Kitle iletişim araçlarındaki muazzam gelişmelere bağlı olarak sığınmacıların kendi ülkelerinden veya dünyanın herhangi bir yerinden haber almasının imkân dahilinde olduğu anlaşılmaktadır. Bu da sığınmacıların beklentilerinin karşılanmadığı durumlarda onlara alternatif göç mekanlarını arama imkanı sunmaktadır.

Tablo 23. Katılımcıların Gelecekten Beklentilerine Göre Dağılımı

\begin{tabular}{lcc}
\hline Değişkenler & F & $\%$ \\
\hline Geçimimi sağlayacak bir iş bulmak & 27 & 20,1 \\
Suriye'ye dönmek & 49 & 36,6 \\
Avrupa ülkelerine göç etmek & 16 & 11,9 \\
Türkiye'de yaşamaya devam etmek & 35 & 26,1 \\
Diğer & 7 & 5,2 \\
Toplam & 134 & 100,0 \\
\hline
\end{tabular}

Yaşanan kitlesel göçlerde iyi bir entegrasyon süreciyle gelenlerin beklentilerinin karşılanmaması durumu ikinci ve üçüncü göç dalgalarını beraberinde getirebilmektedir. Katılımcılara gelecekten ne gibi beklentilerinin olduğu sorulmuş, sığınmacıların 49'u $(\% 36,6)$ Suriye'ye dönmek istediğini, 35’i 
$(\% 26,1)$ Türkiye'de yaşamak istediklerini, 27'si $(\% 20,1)$ geçimini sağlayacak bir iş bulma beklentisi içinde olduğunu, 16'sı $(\% 11,9)$ Avrupa ülkelerine göç etmek istediklerini belirtmişlerdir. Kendi ülkelerine dönmek veya başka bir ülkeye göç etmek istemelerinin altında yatan neden, göçün temel motivasyonu olan daha iyi bir yaşam beklentisi ile daha iyi fırsatlar sunabilecek başka bir ülkeye ya da aidiyet sorunlarını belki daha az yaşayacakları memleketlerine dönme arzusu olarak söylenebilir.

Tablo 24. Katılımcıların Türkiye Cumhuriyeti Vatandaşlığına Geçme Konusunda Taleplerine Göre Dağılımı

\begin{tabular}{lcc}
\hline Değişkenler & F & $\%$ \\
\hline Evet & 47 & 35,1 \\
Hayır & 36 & 26,9 \\
Kararsızım & 40 & 29,9 \\
Vatandaşlığa geçtim & 11 & 8,2 \\
Toplam & 134 & 100,0 \\
\hline
\end{tabular}

Göç ve sığınmacı döngüsünde vatandaşlığa kabul, entegrasyon süreçlerinde önemli bir işleve sahiptir. Sığınmacıların elde edeceği bu türden bir hukuki statü, entegrasyon sürecinde yaşadıkları birçok sorunun çözümüne de katkı sağlayacaktır (Gülyaşar, 2017:703; Yıldız, 2017). Tablo 24 incelendiğinde her ne kadar vatandaşlığa geçiş konusunda sığınmacıların 47'si $(\% 35,1)$ istekli görünse de, genel olarak kararsızların $(\% 29,9)$ ve geçmek istemeyenlerin oranın $(\% 26,9)$ toplamda daha fazla olduğu söylenebilir.

Tablo 25. Katılımcıların Türkiye'ye Göç Etmeden Önceki Beklentilerine Göre Dağılımı

\begin{tabular}{lcc}
\hline Değişkenler & F & $\%$ \\
\hline Vatandaşlığa kabul edilmesi & 28 & 20,9 \\
İş olanaklarının sunulması & 31 & 23,1 \\
Temel insani ihtiyaçlarının karşılanması & 22 & 16,4 \\
Başka ülkeye göç fırsatı & 8 & 6,0 \\
Hiçbir şey & 45 & 33,6 \\
Toplam & 134 & 100,0 \\
\hline
\end{tabular}


Katılımcıların beklenti düzeylerini belirlemek amacıyla Türkiye'ye gelmeden önceki beklentileri sorulmuş, katılımcıların 45’i $(\% 33,6)$ hiçbir beklenti içine girmediklerini belirtmiştir. Geri kalanların içinde 31'i $(\% 23,1)$ iş olanakları olacağı, 28 'i $(\% 20,9)$ vatandaşlığa kabul edileceği, 22'sı $(\% 16,4)$ temel gereksinimlerinin karşılanacağı, 8'i $(\% 6,0)$ başka ülkeye göç fırsatı doğacağı beklentisi içinde olduklarını belirtmişlerdir. Buradan hareketle iş, aş ve vatandaşlığa kabul önemli beklentiler olarak karşımıza çıkmakta ve koşullarının tamamen sağlanamamasından dolayı söz konusu beklentilerin karşılanamadığı anlaşılmaktadır.

Tablo 26. Katılımcıların Geleceğe Umutla Bakma Durumuna Göre Dağılımı

\begin{tabular}{lcc}
\hline Değişkenler & F & $\%$ \\
\hline Çocuklarım için umutluyum & 32 & 23,9 \\
Güvende olduğum için umutluyum & 13 & 9,7 \\
Savaş biteceği için umutluyum & 18 & 13,4 \\
İnançlı olduğum için umutluyum & 21 & 15,7 \\
Türkiye'de yasayacağım için umutluyum & 7 & 5,2 \\
Umutsuz yaşanamayacağı için & 9 & 6,7 \\
Toplam(Umutla bakanlar) & 100 & 74,6 \\
Umutla bakmayanlar & 14 & 11,2 \\
Kararsızlar & 20 & 14,9 \\
Genel Toplam & 134 & 100,0 \\
\hline
\end{tabular}

Katılımcılara geleceğe umutla bakıp bakmadıkları sorulmuş, sığınmacıların büyük çoğunluğu $(\% 73,9)$ gelecekten umutlu olduklarını, 20'si $(\% 14,9)$ kararsız olduğunu, 14’ü $(\% 11,2)$ geleceğe umutla bakamadığını belirtmiștir. Geleceğe umutla bakanların umutlu olma nedeni olarak genel olarak çocuk sahibi olmalarından kaynaklandığı ortaya çıkmıştır. Buna göre sığınmacıların 32'si $(\% 23,9)$ çocukları için geleceğe umutla baktığını, 21’i $(\% 15,7)$ inancı gereği umutsuz olmaması gerektiğini belirtmiş; sığınmacıların 18'i $(\% 13,4)$ savaşın biteceğine inandığından dolayı geri kalanların da güvende hissettikleri ve umutsuz yaşanamayacağından dolayı geleceğe umutla baktıkları ortaya çıkmıştır. Türkiye'de yaşayacağı için geleceğe umutla bakanların oranı çok düşük düzeyde $(\% 5,2)$ kalmıştır. 
Tablo 27. Katılımcıların Göç Öncesinde Sahip Oldukları Dini İnançlarını, Gelenek Ve Göreneklerini Yaşayıp Yaşamadıklarına Göre Dağılımı

\begin{tabular}{lcc}
\hline Değişkenler & F & $\%$ \\
\hline Kesinlikle Katılmıyorum & 18 & 13,4 \\
Katılmıyorum & 20 & 14,9 \\
Kararsızım & 38 & 28,4 \\
Katılıyorum & 28 & 20,9 \\
Kesinlikle Katılıyorum & 30 & 22,4 \\
Toplam & 134 & 100,0 \\
\hline
\end{tabular}

Katılımcılara "göç öncesinde sahip oldukları dini inançları, gelenek ve göreneklerimi yaşıyorum” şeklinde yöneltilen likert ölçekli soruya, genel olarak katılımcıların çoğu $(\% 28,4)$ kararsız olduklarını belirtmekle birlikte 58 'i $(\% 43,3)$ eski gelenek ve göreneklerini sürdürdüklerini belirtmişlerdir.

Tablo 28. Katılımcıların Göç Sonrası Kültürlerini Ve Geleneklerini Yaşamalarından Dolayı Dışlanma, Ayıplanma Yașayıp Yașamadıklarına Göre Dağılımı

\begin{tabular}{lcc}
\hline Değişkenler & $F$ & $\%$ \\
\hline Kesinlikle Katılmıyorum & 38 & 28,4 \\
Katılmıyorum & 27 & 20,1 \\
Kararsızım & 52 & 38,8 \\
Katılıyorum & 12 & 9,0 \\
Kesinlikle Katılıyorum & & 3,7 \\
Toplam & 5 & 134 \\
\end{tabular}

Katılımcılara göç sonrası yaşadıkları kültür ve geleneklerinden dolayı dışlanma, ayıplanma yaşayıp yaşamadıkları sorulmuş, 52'si $(\% 38,8)$ kararsız olduklarını, 38'i $(\% 28,4)$ kesinlikle böyle bir şeyi yaşamadıklarını, 27'si $(\% 20,1)$ böyle bir şeye katılmadıklarını belirtmişlerdir. Az da olsa $(\% 12,7)$ dışlanma ve ayıplanma 
yaşadığını doğrudan belirtenler de ortaya çıkmıştır. Buradan hareketle katılımcıların Batman kent merkezinde gelenek ve görenekleri yaşama konusunda genel olarak herhangi bir sıkıntı yaşamadıklarını Tablo 27 ve Tablo 28'den çıkarım yapabiliriz.

Tablo 29. Katılımcıların Başka Bir Kente Ya Da Ülkeye Göç Etme İsteğine Göre Dağılımı

\begin{tabular}{lcc}
\hline Değișkenler & F & $\%$ \\
\hline Kesinlikle Katılmıyorum & 27 & 20,1 \\
Katılmıyorum & 30 & 22,4 \\
Kararsızım & 48 & 35,8 \\
Katılıyorum & 14 & 10,4 \\
Kesinlikle Katılıyorum & 15 & 11,2 \\
Toplam & 134 & 100,0 \\
\hline
\end{tabular}

Katılımcılara imkânları olması halinde başka bir kente ve ülkeye göç etmek isteyip istemedikleri sorulmuş, katılımcıların 48'i $(\% 35,8)$ kararsız olduklarını, geri kalanların önemli bir bölümü $(\% 42,5)$ ise imkânları olsa bile göç etmek istemediklerini belirtmişlerdir. Yine de $29(\% 21,6)$ katılımcı imkân olması halinde başka yere tekrar göç etmek istediklerini ifade etmişlerdir.

\section{Sonuç ve Değerlendirme}

Sonuç olarak bu çalışmada, savaşın başladığı 2011 yılından beri Batman kent merkezine göç eden farklı veya benzer sosyo-ekonomik ve kültürel özelliklere sahip Suriyeli sığınmacıların sorunlu bir entegrasyon süreci geçirdikleri ortaya çıkmıştır. Başka bir ifadeyle bu çalışma göstermektedir ki sezgisel olanın aksine entegrasyon sürecinin çok sancılı geçtiği ve sosyo-ekonomik ve kültürel açıdan bu sürecin hâlâ tamamlanamadığıdır. Diğer taraftan gelecek beklentileri konusunda genel olarak karamsar görünen Suriyeli sığınmacıların hala umutlarını kaybetmedikleri de söylenebilir. Dolayısıyla bu araştırmadan elde edilen verilerden yola çıkarak böyle bir çalışmanın literatürdeki çoğu kuramsal ve ampirik yapılan çalışmaların verileriyle karşılaştırıldığında bazı konularda farklılaştığı, birçok konuda ise benzer bulgular elde edildiği anlaşılmaktadır. Buradan yola çıkarak aşağıda belirtilen sonuçlar çıkarılabilir. Bunlar; 
Katılımcıların içinde genel olarak evli, genç ve çocuk nüfusun fazla olduğu, genç olanların çoğunun kadınlardan oluştuğu ortaya çıkmıştır. Öğrenim düzeyi açısından okuma yazma oranlarının Türkiye'deki genel sığınmacı profiline göre yüksek olduğu tespit edilmiştir. Nitekim Erdoğan'ın (2019) yaptığı çalışmada, Kirişçi'nin (2014) UNICEF verilerine dayanarak yaptığı değerlendirmede ve Sayın, Usanmaz ve Aslangiri'nin (2016) yaptığı araştırmada; Suriyelilerin yarısından fazlasının okuma ve yazma bilmediği ve çocukların çoğunun eğitim olanaklarından yararlanamadığı tespit edilmiştir.

Katılımcıların Türkiye'yi tercih etmesi konusunda mekânın yakınlığı ve güvenliği ön plana çıkmaktadır. Bunun dışında kentin sanayileşme ve kentleşme açısından gelişmiş olması da göç edenlerin tercihlerini etkilemiştir. Ayrıca göç edenlerin farklı yıllarda ve farklı kentlerden göç etmeleri, Suriye'deki iç savaşın farklı kentlerde ve farklı dönemlerde gerçekleştiğini göstermektedir. Yine elde edilen bulgulardan, Batman’a gelen sığınmacıların büyük çoğunluğunun 2011-2016 yılları arasında göç ettiği ve bunların önemli bir bölümünün ise Haseki kentinden geldiği ortaya çıkmıştır.

Katılımcıların Türkiye'ye geldikten sonra karşılaştıkları en önemli sorun dil, yüksek kiralar ve iş bulamama sorunları olarak karşımıza çıkmaktadır. Bulut, Kayagil ve Karpuz'un da (2016) Kilis'teki Suriyeli sığınmacıların sağlık sektöründe yaşadıkları iletişim sorunları üzerinde yaptığı araştırmada, dil faktörü en önemli sorun olarak karşımıza çıkmaktadır. Dil konusundaki sorunlara ilişkin genel olarak Türkçe konuşamadığı için resmi dairelerde derdini anlatamama, farklı dilde konuştuğu için insanların dikkatini çekme, dersleri anlamakta zorlanma, okula gidememe veya okulda dışlanma gibi başlıklar ön plana çıkmaktadır. Diğer taraftan eğitim ve sağlık konusunda da sığınmacıların önemli oranda sorun yaşadıkları tespit edilmiştir. Eğitim sorunlarının başında ise dil problemi, defter ve kitap alamama, çocuklarını okula gönderememe ve çocuklarının okul arkadaşlarıyla uyum sorunu yaşaması olarak gösterilmiştir. Sağlık sorunlarında ise dil problemi, başta doktorlar olmak üzere sağlık çalışanlarının yaklaşımı, ilaç ve tedavi masraflarını karşılayamama gibi sorunlar karşımıza çıkmaktadır.

Suriye'ye geri dönme konusunda katılımcıların hem istekli hem de beklenti içinde olmaları, Türkiye'ye göç etmeden önceki beklentilerinin tam olarak karşılanmadığına bağlanabilir. Çünkü sığınmacıların büyük çoğunluğunun Türkiye'ye gelmeden önceki ana beklentisi, "eğitim ve sağlık gibi temel insani ihtiyaçlarının karşılanması” olduğu belirtilmiştir. Ancak sığınmacıların çoğunun tüm yaşanan sıkıntılara rağmen çocukları için de olsa geleceğe umutla bakmak istedikleri söylenebilir.

Katılımcıların gelir düzeylerinin genel olarak düşük olduğu ve bu nedenle geçimlerini Suriye'deki mesleklerinden bağımsız olarak daha çok esnafın yanında çalışarak ya da inşaat, hırdavat, eskici ve diğer günlük tutulan vasıfsı işlerden elde ettikleri tespit edilmiştir. Geri kalanların ise geçimini AFAD desteği, halkın yardımı, STK, kendi birikimleri ve diğer yardımlardan yararlanarak karşıladıkları söylenebilir. 
Katılımcıların genel olarak vasıfsız olmaları veya herhangi bir meslek sahibi olmamaları ise Türkiye'nin insani yönü ön plana çıkartarak, gelenlerin vasıflı veya vasıfsız olmalarına bakılmaksızın kabul etmesine bağlanabilir. Ayrıca vasıfsız olanların veya meslek sahibi olmayanların çoğunlukta olması katılımcıların iş bulmada sıkıntı yaşamalarına veya düşük ücretli işlerde çalışmalarına da neden olduğu söylenebilir. Akdeniz'in (2014) İstanbul, İzmir, Adana, Gaziantep, Hatay ve Kayseri'de sığınmacı işçilerle yaptığı röportajlarda; Yıldırımalp vd.'nin (2017) İstanbul'da; İncili ve Akdemir'in (2016) Kilis'te yaptıkları araştırmalarda da işsizlik, düşük ücret ve kayıt dışı istihdam ya da vasıfsız işlerde çalışma gibi benzer ekonomik uyum sorunlarının ortaya çıktığı belirtilmiştir. Katılımcıların çoğunun kirada kaldıkları ve bunların önemli oranının barınma ve beslenme sorunu yaşadıkları ortaya çıkmıştır. Barınma sorunlarının başında yüksek kira ücretleri gelirken kalınan yerin havasız, kalabalık ve kirli olması, kalınan yerde ısınmasoğutma ve aydınlatmanın olmaması gibi sorunlar tespit edilmiştir. Entegrasyonun en önemli unsuru olan beslenme ile ilgili hâlâ bazı öğünlerde yemek yiyemeyenlerin olması merkezi ve yerel yönetimlerin son on yılık politikalarını gözden geçirmeleri gerektiğini ortaya koymaktadır. Bunun yanında sığınmacıların büyük çoğunluğu protein içerikli (et vb.) yiyeceklere hiçbir şekilde ulaşamadıkları da söylenebilir.

Katılımcıların sinema, tiyatro ve spor gibi sosyal ve kültürel aktivitelere katılım sağlayamadıkları, göç öncesinde sahip oldukları dini inançları, gelenek ve görenekleri devam etme konusunda sorun yaşadıkları ortaya çıkmıştır. Duğan ve Gürbüz'ün (2018) yaptığı çalışmada ise bu çalışmanın aksine sığınmacıların sinema, tiyatro ve spor gibi sosyal ve kültürel aktivitelere katılım sağlayabildikleri belirtilmiştir. Yaşanan tüm bu sıkıntılardan dolayı sığınmacıların önemli oranının başka yere göç etme konusunda da istekli olduğu anlaşılmıştır. Entegrasyonun son halkasını oluşturan vatandaşlık konusunda da katılımcıların önemli bir bölümünün istekli olmaması, entegrasyonun tam olarak sağlanamadığını bize göstermektedir. Vatandaşlığa geçme konusunda da farklı sonuçlar, Türk (2020b) ve Gülyaşar'ın (2017) çalışmalarında karşımıza çıkmaktadır. Bu çalışmalarda, Suriyelilerin vatandaşlığa geçme konusunda genel olarak istekli oldukları ve entegrasyonda karşılaştıkları birçok sorununun çözümü için bir fırsat olarak gördükleri anlaşılmaktadır.

Yukarıda belirtilen alan araştırması sonuçlarına göre Batman'da yaşayan sığınmacıların savaşın başından itibaren göç etmelerine rağmen entegrasyon süreçlerinde beklentilerin karşılanmadığı anlaşılmaktadır. Bunun birçok nedeni bulunmakla birlikte genel olarak 1951 tarihli Birleşmiş Milletler Mültecilerin Hukuki Statüsüne iliş̧kin Sözleşmesi'ne ve 1967 New York Protokolü'ne getirilen çekinceler yüzünden mülteci haklarından yararlanamama, mevcut yasalardan kaynaklı yerel yönetimlerin yerelde yaşayan sığınmacılara ilişkin herhangi bir politika geliştirememesi nedeniyle merkezî ve yerel politikalar arasında ortaya çıkan farklılıklar olarak gösterilebilir (Kaypak, Bimay ve Yılmaz, 2017). Suriye'de iç savaşın sürmesinden kaynaklanan yeni göç öngörülmesi ve mevcut sığınmacıların 
geri dönüşlerinin şimdilik mümkün görünmemesi nedeniyle sığınmacı sorunun Türkiye'nin gündemini meşgul etmeye devam edeceği görülmektedir (Erdoğan, 2019). Kuşkusuz Türkiye son on yıllık süreçte, Suriyeli sığınmacıların mikro ve makro açıdan tam entegrasyonunu sağlayamamış, ancak bu denli bir göç dalgasına karşı tüm eksikliklerine rağmen insani ve ahlaki değer yargıları ön planda tutarak mücadele etmeye çalışmıştır. Özellikle içişleri Bakanlığı, MEB ve Sağlık Bakanlığı'nın uyumlaştırma çalışmaları, entegrasyonu kolaylaştıııcı kurumsal çabalar olarak karşımıza çıkmıştır. Yine de dört milyona yaklaşan sığınmacının entegrasyon sürecinin kolay olamayacağı gelinen süreçte anlaşılmış ve son on yılda sürdürülen politikaların yeniden gözden geçirilmesi gerekliliği ortaya çıkmışıır. Bu nedenle ülkemizde kalıcı hale gelen sığınmacıların temel insani gereksinimlerinin yanında mülteci statüsüne kavuşturularak vatandaşlık dahil gerekli tüm haklardan yararlanmalarını sağlayacak "coğrafi sınırlama"nın kaldırılması; göç ve sığınmayla ilgili başta yerel yönetimler olmak üzere ulusal ve ulus-üstü tüm yetkili kurum, kuruluşlar arasında işbirliği, koordinasyon ve eşgüdümün sürdürülebilir hale getirilmesi için her türlü tekniğin kullanılması ve bunun için gerekli tüm finansal kaynakların sağlanması gerekir. Avrupa Birliği (AB), UNHCR gibi uluslararası kuruluşların etkisinde gelişen göç politika süreçlerinin daha öznel politikalarla sürdürülmeye çalışılması, özellikle kitlesel göçlerde hızlı ve etkin çözüm almak için entegrasyonun temel göstergeleri olan barınma, beslenme, eğitim, sağlık ve dil gibi unsurların yerine getirilmesinde yerel yönetimlere daha çok yetkilendirme yapılması göç yönetimi açısından önemli katkılar sağlayacaktır. Bununla, özellikle yerelde Suriyelilerin kendini önemsiz görme, yabancılaşma, dışlanma gibi psikolojik ve sosyolojik çözülmelerinin de önüne geçilmiş olacak ve geleceğe daha umutla bakmalarını sağlayacaktır.

\section{Kaynakça}

Agblorti, S. K. (2011). Refugee Integration in Ghana, The Host Community's Perspective. UNHCR, Policy Development And Evaluation Service. 20 Haziran 2020 tarihinde https://www.unhcr.org/research/working/ pdf. adresinden erișildi.

Ager, A. \& Strang, A. (2004). Indicatiors of Integration: Final Report, Home Office Development and Practice Report 28, Queen Margaret University College, Edinburgh. $12 \quad$ Haziran 2020 tarihinde https://webarchive.nationalarchives.gov.uk/20110218141321/http://rds.homeo ffice.gov.uk/rds/pdfs04/dpr28.pdf. adresinden erișildi.

Akdeniz, E. (2014). Suriye savaşının gölgesinde mülteci iş̧̧iler. İstanbul: Evrensel Basım Yayın.

Akkayan, T. (1979). Göç ve Değişme. İstanbul: İstanbul Üniversitesi Edebiyat Fakültesi Yayınları.

Aksoy, Z. (2012). Uluslararası Göç Ve Kültürlerarası Illetişim. Uluslararası Sosyal Araştırmalar Dergisi, 5(20), 1307-9581. 12 Haziran 2020 tarihinde http://sosyalarastirmalar.com/..pdf. adresinden erişildi. 
Berry, J. W.(1997). İmmigration, Acculturation, And Adaptation Applied Psychology: An Internatıonal Review. Applıed Psychology, Volume 46, Issue 1,January, 5-34. 02 Mayı 2020 tarihinde https://iaapjournals.onlinelibrary.wiley.com/doi/10.1111/j.1464-0597.1997.tb01087.x. adresinden erişildi.

Boos-Nünning, U. (2007). Almanya'daki Türk Kökenli Genç Göçmenlerin Topluma Entegrasyonu: Kültürlerarası Eğitim. Ayhan Kaya ve Bahar Şahin (Ed.). Kökler ve Yollar: Türkiye'de Göç Süreçleri içinde (205-220). İstanbul: Bilgi Üniversitesi Yayınları.

Bulut, Ş, Kayagil, T. \& Karpuz N. (2016) Suriyeli Sığınmacılarla Sağlık Sektöründe Yaşanan İletişim Sorunları Üzerinde Bir Araştırma: Kilis İli Örneği, Mustafa Paksoy, Kazım Sarıçoban, Elif Yildirimci, Özcan Özkan (Ed.), II. Uluslararası Ortadoğu Konferansları: Ortadoğu'daki Çatışmalar Bağlamında Göç içinde (295-313), Kilis: Kilis 7 Aralık Üniversitesi İktisadi Ve İdari Bilimler Fakültesi.

Bulut, Y. \& Eraldemir, Z. (2015). Göç Olgusunun Farklı Boyutlarıyla Hatay ili İskenderun ve Dörtyol i̇ç̧eleri Ölçeğinde İncelenmesi. Yakup Bulut (Ed.), Uluslararası Göç ve Mülteci Sorunun Çözümünde Kamu Yönetiminin Rolü içinde (13-38), Kocaeli: Umuttepe Yayınları.

Castles, S. ve Mıller, M. J. (2008). Göçler Çağı: Modern Dünyada Uluslararası Göç Hareketleri. (Çev.: Bülent Uğur Bal ve İbrahim Akbulut), (1. Baskı), İstanbul: İstanbul Bilgi Üniversitesi Yayınları.

Chambers, I. (2014). Göç, Kültür, Kimlik. İstanbul: Ayrıntı Yayınları.

Chambers, R. (1986). Hidden Losers? The Impact of Rural Refugees and Refugee

Programs on Poorer Hosts. International Migration Review, 20 (2), 245-263.

Erişim Adresi: https://www.jstor.org/stable/2546034?seq=1.

Çoban, Ö., Dilek, E., S. \& Harman, S. (2017). Batman İlinde Turizm Gelişiminin Değerlendirilmesi. International Journal Of Social Science, Doi No: 56, 437455. 5 Temmuz 2020 tarihinde https:// www. researchgate.net/publication/322405713_PDF. adresinden erișildi.

De Tapıa, S. (2003). New Patterns Of İrregular Migration In Europe. Seminar Report 12 And 13 November 2002, Strasbourg: Council Of Europe.

Duğan, Ö. \& Gürbüz, S. (2018). Suriyeli sığınmacıların sosyal entegrasyonuna yönelik bir araştırma. Electronic Turkish Studies, 13 (26), 529-546. DOI: 10.7827/TurkishStudies. 14625.

Elitok, S.P. (2019). Three Years on: An Evaluation of the EU-Turkey Refugee Deal. MiREKOÇ Yayınları. 03 Haziran 2020 tarihinde https://mirekoc.ku.edu.tr/.pdf. adresinden erişildi.

Erdoğan, M. (2019). Türkiye'deki Suriyeli Mülteciler. Konrad Adenauer Stıftung (KAS). $23 \quad$ Eylül $2020 \quad$ tarihinde https://www.kas.de/documents/283907/7339115/PDF. adresinden erişildi.

Es, M. \& Ateş, H. (2004). Kent Yönetimi, Kentlileşme ve Göç: Sorunlar ve Çözüm Önerileri. Sosyal Siyaset Konferansları Dergisi. Sayı:48, i..̈̈.i.F. Yayını, 205-248. 13 Haziran $2020 \quad$ tarihinde https://dergipark.org.tr/tr/pub/iusskd/issue/89o/9892. adresinden erișildi. 
Faist, T. (2003). Uluslararası Göç ve Ulusaşırı Toplumsal Alanlar. (Çev: Azat Zana Gündoğan ve Can Acar), Ankara: Bağlam Yayınları.

Fielden, A. (2008). Local integration:An under-reported solution to protracted refugee situations. New Issues In Refugee Research, Research Paper No. 158. Intern, Policy Development and Evaluation Service, UNHCR. https://doi.org/10.1111/j.1464-0597.1997.tb01087.

Göç İdaresi Genel Müdürlüğü (2020). 11 Mayıs 2020 tarihinde https://www.goc.gov.tr/. adresinden erişildi.

Gülyaşar, M. (2017). Suriyeliler ve Vatandaşlık: Yerel Halk ve Suriyeli Sığınmacılar Çerçevesinde Bir Değerlendirme. Uluslararası Toplum Araștırmaları Dergisi(OPUS), (7/13), 678-705.International Organization for Migration (2020). 22 Temmuz 2020 tarihinde https://www.iom.int/. adresinden erişildi.

International Organization for Migration (2013) Göç Terimleri Sözlüğü, Richard Perruchoud ile Jillyanne Redpath-Cross (Ed.), 2. Baskı, IOM Yayınları, No:31

İçduygu A., Erder, S. \& Gençkaya, Ö. F. (2014). Türkiye'nin Uluslararası Göç Politikaları, 1923-2023: Ulus-Devlet Oluşumundan Ulus-Ötesi Dönüşümlere. MIREKOÇ Proje Raporları 1/2014 TÜBITAK 1001_106k291, İstanbul: KOÇ Üniversitesi $\quad$ Yayınları. $22 \quad$ Temmuz 2020 tarihinde https://mirekoc.ku.edu.tr/wp-content/uploads/2017/01-.pdf. adresinden erişildi.

İçduygu, A. \& E. Millet (2016). Syrian Refugees in Turkey; Insecure Lives in an Environment of Pseudo-Integration." Global Turkey in Europe Series, Working Paper 13. 22 Temmuz 2020 tarihinde

http://www.iai.it/sites/default/files/gte wp 13.pdf. adresinden erişildi.

İçduygu, A., \& Aksel, D. B. (2013). Turkish Migration Policies: A Critical Historical Retrospective. Perceptions, XVIII(3), 167-190. 02 Temmuz 2020 tarihinde http://sam.gov.tr/.pdf. adresinden erișildi.

Incili Ö. F. \& Akdemir i (2016). Yerinden Edilmişliğin Coğrafi Analizi: Kilis'te Suriyeli Sığınmacılar. Marmara Coğrafya Dergisi. o (34), 118-133.

Joppke, C. (2012). The Role Of The State Cultural Integration: Trends. Challenges And Ways Ahead, Washington: MPI Yayını 7 Temmuz 2020 tarihinde https://www.migrationpolicy.org/research/pdfadresinden erișildi.

Karen J. (2006). Refugees and Asylum Seekers in Urban Areas: A Livelihoods

Perspective. Journal of Refugee Studies, Volume 19, Issue 3, Pages 273-286,

8Temmuz 2020 tarihinde https://doi.org/10.1093/jrs/fel017. adresinden erișildi. Kaypak, Ş. \& Bimay, M.(2016). Suriye Savaşı Nedeniyle Yaşanan Göçün Ekonomik ve Sosyo-Kültürel Etkileri: Batman Örneği, Batman Üniversitesi Yaşam Bilimleri Dergisi, 6 (1), 84-110. 9 Haziran 2020 tarihinde https://www.academia.edu/30714297/pdf. adresinden erișildi.

Kaypak, Ş., Bimay, M. \& Yılmaz, V. (2017). Uluslararası Göç ve Mülteci Sorunlarının Çözümünde Yerel Yönetimlerin Rolü: Batman Örneği. Göç ve Yerel Yönetimler içinde (1179-1194). Uluslararası 11. Kamu Yönetimi Sempozyumu, Elazığ.

Keleş, R. (1998). Kentbilim Terimleri Sözlüğü, Ankara: İmge Kitabevi. 
Kirişci,K. (2014). Syrian Refugees And Turkey's Challenges: Going Beyond Hospitality. BROOKINGS, Washington. 12. 09. 2020 tarihinde http: /l madde14.org/english/images/o/oe/2014BrookingsSyriaKirisci.pdf. adresineden erişildi.

Kirişçi K. \& Karaca, S.(2015). Hoşgörü ve Çelişkiler: 1989,1991 ve 2011'de Türkiye'ye Yönelen Kitlesel Mülteci Akımları. M.Murat Erdoğan \& Ayhan Kaya (Ed.), Türkiye'nin Göç Tarihi-14. Yüzyıldan 21. Yüzyıla Türkiye'ye Göçler içinde (295314), İstanbul: İstanbul Bilgi Üniversitesi Yayınları.

Kurekova, L. (2011). Theories of migration: Conceptual review and empirical testing in the context of the EU East-West flows. Paper prepared for Interdisciplinary conference on Migration. Economic Change, Social Challenge. April 6-9, 2011, University College London. 16 Mayıs 2020 tarihinde https://pdfs.semanticscholar.org/pdf. adresinden erişildi.

Kymlicka, W. (2012), Çok Kültürlülük: Başarı, Başarısızlık Ve Gelecek. İstanbul Üniversitesi Hukuk Fakültesi Dergisi, Çev.: Fatih Öztürk, 70 (2), 297-332. 12 Mayıs 2020 tarihinde https://dergipark.org.tr/tr/pub/iuhfm/issue/9187/115144. adresinden erişildi.

Penninx, R. \& Spencer, D.(2008), Migration And Integration In Europe: The State Of Research, Oxford Üniversitesi Ve Esrc Yayını. 5 Mayıs 2020 tarihinde https://www.researchgate.net/publication/237539737_pdf._adresinden erişildi.

Philips, C. (2012). Turkey's Syria Problem. Public Policy Research, IPPR, Vol.19, No. 2, 137-140. $24 \quad$ Mayı $2020 \quad$ tarihinde

https://www.researchgate.net/publication/263143648_pdf._adresinden erişildi.

Punch, K. F. (2011). Sosyal Araştırmalara Giriş/Nicel ve Nitel Yaklaşımlar. (Çev.: Dursun Bayrak, H. Bader Arslan \& Zeynep Akyüz), Ankara: Siyasal Kitapevi.

Sayın, Y., Usanmaz, A. \& Aslangiri, F.(2016). Uluslararası göç olgusu ve yol açtığı etkiler: Suriye göçü örneği. KMÜ Sosyal ve Ekonomik Araştırmalar Dergisi, 18 (31), 1-13

Tekeli, İ. \& Erder, L. (1978). Yerleşme Yapısının Uyum Süreci Olarak İç Göçler. Ankara: Hacettepe Üniversitesi Yayınları.

The UN Refugee Agency (2020). 24 Mayı 2020 tarihinde https://www.unhcr.org/asylum-and-migration.html adresinden erişildi.

Tuncel, M. (1992). İslam Ansiklopedisi, Cilt.5, İstanbul: TDV Yayınları.

Türk, E. (2020). Petrol, Göç ve Değişim Batman Kentleşmesi. İstanbul: Çizgi Kitabevi.

Türk, E. (2020). Suriyeli Göçmenlerin Türk Vatandaşlığı Hakkındaki Görüş ve Beklentileri. Selçuk Ün. Sos. Bil. Ens. Der., (43), 162-176.Walsh, P. R. (2011). Creating a "Values" Chain For Sustainable Development in Developing Nations: Where Maslow Meets Porter. Environment, Development and Sustainability, 13(4): 789-805. 11 Mayı 2020 tarihinde https://link.springer.com/content/pdf/10.1007/s10668-011-9291-y.pdf. adresinden erişildi. 
Onuncu Yılında Suriyeli Sığınmacıların Kente Entegrasyonu ve Gelecek Beklentileri: Batman Örneği

Yıldırımalp, S., İslamoğlu, E. \& İyem, C. (2017). Suriyeli sığınmacıların toplumsal kabul ve uyum sürecine ilişkin bir araştırma. Bilgi, 19(2), 107-126. 30 Mayıs 2020 tarihinde https://dergipark.org.tr/tr/download/article-file/453989. adresinden erișildi.

Yıldız, A. (2017). Göç ve Entegrasyon Politikalarında Vatandaşlık. Göç Araştırmaları Dergisi, No.1, 36-68 